Original scientific paper

\title{
ANALYSIS OF BUCKWHEAT PRODUCTION IN THE WORLD AND SERBIA ${ }^{1}$
}

\author{
Vera Popović ${ }^{2}$, Vladimir Sikora ${ }^{3}$, Janoš Berenjï ${ }^{4}$, Vladimir Filipovic ${ }^{5}$, \\ Željko Dolijanović ${ }^{6}$, Jela Ikanović7, Dalibor Dončić ${ }^{8}$
}

\begin{abstract}
Summary
During the period 2010-2011 about 2.113 million ha of buckwheat was sown annually worldwide. Average yield of buckwheat during the monitored period was $913 \mathrm{~kg} \mathrm{ha}$. Areas and average yield have a rising tendency. The most significant producers of buckwheat in the world are: China, Russia and Ukraine. In Serbia buckwheat is produced on small areas.
\end{abstract}

The paper presents results of testing of four buckwheat varieties, produced on plots of the Institute for crops and vegetables as follows: Novosadska, Godijevo, Bamby and Češka. Analysis of average yield has shown that Novosadska variety produced statistically significant higher yield (2626 $\mathrm{kg} \mathrm{ha}^{-1}$ ) compared to the other varieties tested $(p<0.05)$.

From the results shown we can see that buckwheat yield in Serbia is significantly higher compared with the world average yield, which tells us that this plant can be successfully produced in our agro-ecological conditions of growing.

1 Paper is a part of research within the project TR 31022 financed by the Ministry of Education, Science and Technological Development of the Republic of Serbia. Project period: 2011-2014.

2 Vera Popović, Ph.D., Research Associate, Institute of Field and Vegetable Crops, Maksima Gorkog Street 30, 21000 Novi Sad, Serbia, Phone: +381 6482057 33, E-mail: vera.popovic@nsseme.com

3 Vladimir Sikora, Ph.D., Senior Research Associate, Institute of Field and Vegetable Crops, Maksima Gorkog Street 30, 21000 Novi Sad, Serbia, E-mail: vladimir.sikora@nsseme.com

4 Janoš Berenji, Ph.D., Principal Research Fellow, Institute of Field and Vegetable Crops, Maksima Gorkog Street 30, 21000 Novi Sad, Serbia, E-mail: janos.berenji@nsseme.com

5 Vladimir Filipović, Ph.D., Research Associate, Institute for Medicinal Plants Research "Dr Josif Pančić", 11000 Belgrade, Serbia, Phone: +381 6486109 23, E-mail: vfilipovic@mocbilja.rs

6 Željko Dolijanović, Ph.D., Professor, University of Belgrade, Faculty of Agriculture, Nemanjina street 6, 11080 Zemun, Serbia, Phone: +381 6383063 68, E-mail: dolijan@agrif.bg.ac.rs

7 Jela Ikanović, Ph.D., Research Associate, University of Belgrade, Faculty of Agriculture, Nemanjina street 6, 11080 Zemun, Serbia, E-mail: jela@agrif.bg.ac.rs

8 Dalibor Dončić, M.Sc., Syngenta, Meše Selimovića street 12, Gradiška, Bosnia and Herzegovina, Phone: +387 65814 709, E-mail: dalibor.doncic@syngenta.com

EP 2014 (61) 1 (53-62) 
Key words: area, buckwheat-Fagopyrum esculentum, Serbia, yield, world.

JEL: $Q 16, M 24$

\section{Introduction}

Buckwheat (Fagopyrum esculentum Moench) is annual monocarp plant from a group of alternative wheat form family of Poligonaceae, species Fagopyrum (Sharma, Jana, 2002). Primary gene of buckwheat origin is from wider area of Central Asia.

The name of this species is derived from two words fagus (beech) and pyros (beech and wheat). Sown areas in the world in a last decade are doubled, from a million to over two million hectares. This cultivated plant species is notable by its exceptional nutritive values (Popović et al., 2013a, 2013b). In our country, cultivation of buckwheat is cultivated on small areas, mostly in hilly-mountain areas of South-western Serbia, but there is an increasing interest of farmers for the cultivation of this crop in recent years (Glamočlija at al., 2011).

Buckwheat is grown for grain, in other words for nut-like fruits. Buckwheat grain has a great nutritional value, almost like a bread grain crops. 1000-grain weight is 24-30 g (Popović et al., 2013a). Buckwheat grains contain about 52.11\% starch, 11-12.55\% of the total protein, $8.7 \%$ of the pulp, $2.23 \%$ oil, $11 \%$ water and $1.75 \%$ of $\mathrm{N}$ protein (Popović et al., 2013b, 2013c). The most important ingredients of this plant are flavonoids (Arsić et al., 2008). Grain contains a large amount of indispensable amino acids (EAA), primarily lysine and methionine and dietary protein. Shelled fruits can be used as a food in different ways. Complete grain is used as a nutritive supplement for different stews, while flour is used for preparation of porridge (polenta) or mixed with wheat or rye for preparation of bread with higher digestion value. Because of the beneficial chemical composition, and the absence of adhesive proteins, buckwheat is suitable for diabetics and children diets. Buckwheat can be used as siderite to increase natural soil fertility. The highest quality green mass to plough in will be acquired from biomass after flowering, because at that stage it quickly mineralizing the soil and enriches the soil with plant assimilating in a short time (Glamočlija et al., 2011). It is very suitable for crop rotation, because there is no usage of chemical substances for protection (Berenji, 2011, Popović at al., 2013a).

Buckwheat is a plant of modest demands towards environmental conditions; it is also grown on poor soils (Popović at al., 2013a, 2013d, Ikanović at al., 2013). Kreft (1995) pointed out that buckwheat suppresses weeds. The competitive and allelopathic effects of buckwheat towards weeds is better expressed in mountain then lower regions, because cooler summers are more appropriate for buckwheat then thermo-philic weeds (Đukić at al., 2007). Therefore, buckwheat is suitable for organic production.

The goal of this research is to study the analysis of buckwheat production in the world and influence of agro-ecological factors to buckwheat productivity in conditions of Bački Petrovac. 


\section{Materials and methods}

This paper analyses the buckwheat production parameters in the world during the period from 2010 to 2011. The research is based on the available data already existing in related statistical publications. Data from FAO 2013 were used (http:// faostat.fao.org/). For the calculation of the yield and the size of the area, we used a basic statistical method comprising of the following:

- for calculation of variation degree of area size and yield coefficient of variation (CV) was applied in equation: $\mathrm{C}_{\mathrm{v}}=\mathrm{b} \cdot 100 / \bar{X}$

- movement of occurrences was calculated using an exponential trend in equation: $\mathrm{Yt}=\mathrm{a} \cdot \mathrm{b}^{\mathrm{xi}}$.

We used original data from Institute of Field and Vegetables Crops, Novi Sad. Trials were set up on testing from Institute of Field and Vegetables Crops, located in Bački Petrovac, area in the period 2010-2011, on a soil type carbonated chernozem, sub type loess and loess-like sediments, variety of carbonated ogley, in a conventional system of cultivation, in three repetitions. The subjects of research were the following varieties of buckwheat: Novosadska, Godijevo, Bamby and Česka. In conventional system of cultivation basic machining (deep tillage) and fertilizing with mineral fertilizers $15 \times 15$ $\mathrm{x} 15$, in a quantity of $200 \mathrm{~kg} / \mathrm{ha}$ was performed in an optimal time-line. During the field trials standard technology of cultivation was applied. Composition of plants was $50 \times 4$ $\mathrm{cm}$ in an interlinear distance of $50 \mathrm{~cm}$ and depth of $3 \mathrm{~cm}$. The size of basic plot was 10 $\mathrm{m}^{2}$. Pre-sowing preparations and sowing were completed in optimal time-line. Harvest was performed manually in technological ripeness.

Soil in trial plot was of mild alkali reaction ( $\mathrm{pH}$ in $\mathrm{KCl}=7.48$ ), with a lot of humus $2.42 \%$, medium provided with nitrogen $0.184 \%$, highly provided with available phosphorus (33.7 $\mathrm{mg} / 100 \mathrm{~g}$ of soil) and well provided with potassium ( $20.5 \mathrm{mg} / 100 \mathrm{~g}$ of soil).

Grain yield of buckwheat was determined by measuring from every basic parcel and calculated to $13 \%$ of moisture. Analysis of acquired experimental data was performed with descriptive and analytical statistics with use of statistical package STATISTICA 10 for Windows. The testing of significance of differences between calculated average values of analysed factors (year and genotype) was performed with application of two-factor model of variant analysis. All evaluations of significance ware performed on the basis of LSD-test for a level of significance $0.05 \%$ and $0.01 \%$.

\section{Results and discussion}

Buckwheat is planted to an average of 2.113 million hectares worldwide. There is an increasing trend of areas under buckwheat with a rate of $22.46 \%$ per year and variation $(\mathrm{CV}$ $=14.28 \%$ ), Table 1 .

The highest production of buckwheat of $93.67 \%$ in the world was in Europe and on Asian continent (1,133 ha, $846,799 \mathrm{ha})$, that is $53.61 \%$ and $40.06 \%$, respectively. 
The lead producers Europe and Asia have a tendency to increase areas with rate of $38.71 \%$ and $5.01 \%$ respectively. Adequate participation by continents, the most significant producers of buckwheat in the world are: China (34.25\%), Russia (32.43\%), Ukraine (11.46\%) and have trend of increase of areas per rate of $6.85 \%, 47.90 \%$ and $43.86 \%$. While major producers of buckwheat are: Poland (3.38 \%), USA (3.68 \%), Japan (2.46\%), Brazil (2.17\%) and France (1.61 \%). Unlike the most significant world producers, Poland, USA and France have a trend of decreasing the buckwheat production areas, Table 1.

Table 1. Area under buckwheat in the world, 2010-2011

\begin{tabular}{|c|c|c|c|c|c|c|}
\hline Area (ha) & 2010 & 2011 & $\begin{array}{c}\text { Average } \\
\text { values }\end{array}$ & $\begin{array}{c}\text { Rate of } \\
\text { change, } \%\end{array}$ & CV, \% & Share, \% \\
\hline \multicolumn{7}{|c|}{ Continents } \\
\hline World & 1900409 & 2327409 & 2113909 & 22,46 & 14,28 & 100 \\
\hline Europe & 949486 & 1317103 & 1133294 & 38,72 & 22,94 & 53,61 \\
\hline Asia & 816800 & 876798 & 846799 & 7,37 & 5,01 & 40,06 \\
\hline America & 124169 & 123244 & 123706 & $-0,74$ & 0,52 & 5,85 \\
\hline North America & 78269 & 77244 & 77756 & $-1,31$ & 0,93 & 3,68 \\
\hline South America & 45900 & 46000 & 45950 & 0,21 & 0,16 & 2,18 \\
\hline Africa & 10030 & 10264 & 10147 & 1,63 & 2,33 & 0,48 \\
\hline \multicolumn{7}{|c|}{ Countries } \\
\hline China & 700000 & 748000 & 724000 & 6,85 & 4,68 & 34,25 \\
\hline Russian & 570100 & 843200 & 706650 & 47,90 & 27,33 & 33,43 \\
\hline Ukraine & 198600 & 285700 & 242150 & 43,86 & 25,43 & 11,46 \\
\hline Poland & 88525 & 75768 & 82146 & $-14,41$ & 10,98 & 3,88 \\
\hline USA & 78269 & 77244 & 77756 & $-1,31$ & 0,90 & 3,68 \\
\hline Japan & 47700 & 56400 & 52050 & 18,23 & 11,82 & 2,46 \\
\hline Brazil & 45900 & 46000 & 45950 & 0,21 & 0,15 & 2,17 \\
\hline France & 36900 & 31000 & 33950 & $-15,98$ & 12,28 & 1,61 \\
\hline Slovenia & 1198 & 1180 & 1189 & $-1,50$ & 1,07 & 0,06 \\
\hline
\end{tabular}

Source: faostat.fao.org, 2013.

Average yield worldwide in the period 2010-2012 was $913 \mathrm{~kg} \mathrm{ha}^{-1}$ in total and have a tendency to increase with rate of $17.12 \%$. In 2011, a higher yield of $144 \mathrm{~kg} \mathrm{ha}^{-1}$ was produced. Around $68 \%$ buckwheat hectarage is located in Russia and China. Ukraine takes the third place per planted hectarage, followed by significant buckwheat producers Poland, USA, Brazil, Japan, France, etc., Table 2.

The highest average yield per continents was produced in America with $1,115 \mathrm{~kg} \mathrm{ha}^{-1}$. Average yield in America was varying from 1,237 $\mathrm{kg} \mathrm{ha}^{-1}$ in South America to 1,042 $\mathrm{kg} \mathrm{ha}^{-1}$ in North America. The lowest yield was produced in Africa of $848 \mathrm{~kg} \mathrm{ha}^{-1}$ and Asia $890 \mathrm{~kg} \mathrm{ha}^{-1}$. The highest average yield in the world was produced France $(3,173$ $\left.\mathrm{kg} \mathrm{ha}^{-1}\right)$, followed by Brazil $\left(1,237 \mathrm{~kg} \mathrm{ha}^{-1}\right)$, Poland $\left(1,162 \mathrm{~kg} \mathrm{ha}^{-1}\right)$, Slovenia $(1,099 \mathrm{~kg}$ $\mathrm{ha}^{-1}$ ) and USA (1,042 $\left.\mathrm{kg} \mathrm{ha}^{-1}\right)$, Table 2 . 
Table 2. Average yield of buckwheat in the world, 2010-2011

\begin{tabular}{|c|c|c|c|c|c|}
\hline Yield $\left(\mathrm{kg} \mathrm{ha}^{-1}\right)$ & 2010 & 2011 & Average & Rate of change, \% & $\mathrm{CV}, \%$ \\
\hline \multicolumn{6}{|c|}{ Continents } \\
\hline World & 841 & 985 & 913 & 17,12 & 11,15 \\
\hline Europe & 778 & 1027 & 902 & 32,01 & 19,51 \\
\hline Asia & 872 & 908 & 890 & 4,12 & 2,86 \\
\hline America & 1122 & 1108 & 1115 & $-1,24$ & 0,88 \\
\hline North America & 1055 & 1029 & 1042 & $-2,46$ & 1,76 \\
\hline South America & 1.235 & 1.239 & 1237 & 0,32 & 0,22 \\
\hline Africa & 820 & 876 & 848 & 6,83 & 4,66 \\
\hline \multicolumn{6}{|c|}{ Countries } \\
\hline China & 595 & 949 & 772 & 59,49 & 32,42 \\
\hline Russian & 928 & 962 & 945 & 3,66 & 2,54 \\
\hline Ukraine & 673 & 985 & 829 & 46,35 & 26,61 \\
\hline Poland & 1098 & 1227 & 1162 & 11,74 & 7,85 \\
\hline USA & 1055 & 1029 & 1042 & $-2,46$ & 1,76 \\
\hline Japan & 622 & 567 & 614 & $-8,84$ & 6,54 \\
\hline Brazil & 1235 & 1239 & 1237 & 0,32 & 0,22 \\
\hline France & 3411 & 2935 & 3173 & $-13,95$ & 10,26 \\
\hline Slovenia & 1143 & 1055 & 1099 & $-7,69$ & 5,66 \\
\hline
\end{tabular}

Source: faostat.fao.org, 2013.

In our country, buckwheat is cultivated in small areas, mostly in hilly-mountain areas of south-western Serbia. Buckwheat was cultivated at the Institute of Field and Vegetables Crops, Department for alternative plant species, which is located in Bački Petrovac.

\section{Production of buckwheat in Serbia}

\section{Agro-ecological conditions}

Considering that weather conditions are changeable, unstable and unpredictable in certain areas for production of seed, it is necessary to follow varying of outer factors, in order to timely temper climate limiting factors with agro-technical measures (Popović et al., 2011). Data for analysis of weather conditions was used from weather station Bački Petrovac.

More favourable year for a buckwheat production was $2010\left(\mathrm{~T}=18.76^{\circ} \mathrm{C}, \mathrm{P}=636 \mathrm{~mm}\right)$, while unfavourable year was $2011\left(\mathrm{~T}=19.53{ }^{\circ} \mathrm{C}, \mathrm{P}=245.6 \mathrm{~mm}\right)$. Recorded average temperature (T) in 2011 was $19.53{ }^{\circ} \mathrm{C}$ and was $0.77^{\circ} \mathrm{C}$ higher compared to 2010 while quantity of precipitation (P) was lower for $390.4 \mathrm{~mm}$ in relation to 2010.

Limiting factor in 2011 was a deficiency and unfavourable disposition of precipitation in soil during the vegetation period (Graph 1a and 1b). 
Graph 1a and 1b. Average temperature and total precipitation (2010-2011), B. Petrovac
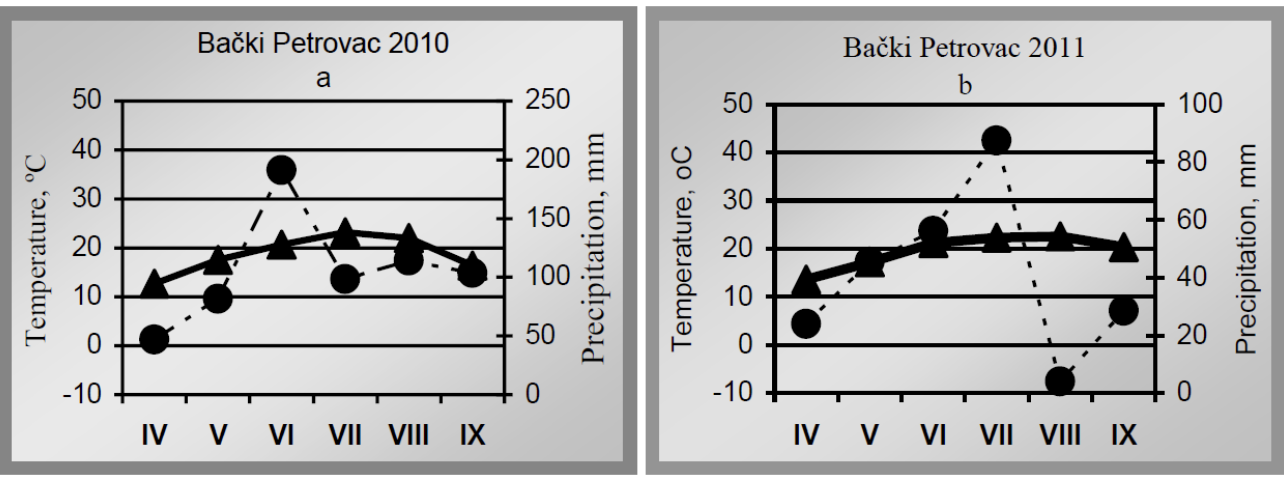

Source: Meteorological station Bački Petrovac, 2010-2011

\section{Buckwheat grain yield}

Average yield of buckwheat in Bački Petrovac for tested varieties in 2010-2011 amounted to $2,263 \mathrm{~kg} \mathrm{ha}^{-1}$ in average. Yield varied from 1,733 $\mathrm{kg} \mathrm{ha}^{-1}$ (2011) to 2,792 $\mathrm{kg} \mathrm{ha}^{-1}$ (2010). The most favourable year for buckwheat production was 2010. Produced buckwheat yield for all tested genotypes in 2010 were significantly higher in relation to $2011(\mathrm{p}<0.01)$. Analysis of average grain yield per varieties showed that Novosadska variety produced statistically significantly higher yield $\left(2,626 \mathrm{~kg} \mathrm{ha}^{-1}\right)$ in relation to other tested varieties $(\mathrm{p}<0.05)$. Year and genotype showed a great significance $(\mathrm{p}<0.01)$, Table 3 .

Table 3. Buckwheat yields (2010-2011), Bački Petrovac

\begin{tabular}{|c|c|c|c|c|}
\hline Source of variation & $\begin{array}{l}\text { Yield, } 2010 \\
\left(\mathrm{~kg} \mathrm{ha}^{-1}\right)\end{array}$ & $\begin{array}{l}\text { Yield, } 2011 \\
\left(\mathrm{~kg} \mathrm{ha}^{-1}\right)\end{array}$ & $\begin{array}{l}\text { Average } \\
\left(\mathrm{kg} \mathrm{ha}^{-1}\right)\end{array}$ & $\mathrm{CV}, \%$ \\
\hline \multicolumn{5}{|l|}{ Variety } \\
\hline Novosadska & 2996 & 2257 & 2626 & 19,89 \\
\hline Godijevo & 2497 & 2103 & 2300 & 11,80 \\
\hline Bamby & 2216 & 1412 & 1814 & 31,34 \\
\hline Češka & 3462 & 1161 & 2312 & 70,39 \\
\hline Average & 2792 & 1733 & 2263 & 33,09 \\
\hline Indicator & LSD test & Year & Genotype & Interaction \\
\hline \multirow{2}{*}{ Yield } & 0.05 & 191 & 270 & 360 \\
\hline & 0.01 & 264 & 373 & 527 \\
\hline
\end{tabular}

Source: Original data from Institute of Field and Vegetables Crops, Novi Sad, 2010 -2011.

Buckwheat varieties Novosadska and Godijevo produced the highest stability of yield, while variety Česka had the highest oscillations $(\mathrm{Cv}=70.39 \%)$. Variety Bamby in researched period produced statistically significantly lower yield in relation to other tested varieties, $\mathrm{p}<0.01$. Interaction of year $\mathrm{x}$ genotype has shown a great significance, $\mathrm{p}<0.05$, Table 3 . 
Weather conditions significantly influenced yield quantity during the researched period. In 2010, all tested genotypes produced exceptionally high yield, which was contributed by sufficient amount of precipitation, balanced allocation, favourable temperatures and proper use of cultural methods. In the same year, the genetic potential of varieties became prominent. Novosadska, Česka and Godijevo varieties were leading in trial fields of Bački Petrovac area.

According to et al (2010), average grain yield of buckwheat from Novosadska variety was in range from $2,216 \mathrm{~kg} \mathrm{ha}^{-1}$ to $3,660 \mathrm{~kg} \mathrm{ha}^{-1}$ in favorable years. In given ecological conditions Prekmurska, Česka, Darja and Čelebica varieties were notable.

According to the research results, it is apparent that Serbia can successfully produce buckwheat, because the average yield of buckwheat was higher than the average world yield of $1,350 \mathrm{~kg} \mathrm{ha}^{-1}$. It is important to mention that buckwheat belongs to a group of melliferous plants and presents an excellent honey-bee pasture. The flowers are rich with nectar. Blooming is successive and lasts a long period of time. There can be up to 2,000 flowers on one plant. From one hectare of buckwheat 100 - $400 \mathrm{~kg}$ of therapeutic honey can be produced (Glamočlija et al., 2011).

A variety of natural conditions and resources allow the use of various agricultural production systems (Popović et al., 2012). In addition, buckwheat is suitable for crop rotation (Nikolić et al., 2010). Chemical substances are not used as a protection measure on buckwheat. Buckwheat has a short vegetation period; it is resistant to drought, therefore, it can be cultivated as a stubble crop. Buckwheat is a plant of modest demands towards environmental conditions.

\section{Conclusion}

Based on the results attained during the research we can conclude the following:

During the period of research buckwheat was planted on approximately 2.113 million ha in the world. Average areas of buckwheat in the world and yield have a trend of increase. Average world yield was $913 \mathrm{~kg} \mathrm{ha}^{-1}$ and there was a recorded trend of increase of $17.12 \%$ and great stability $(\mathrm{Cv}=11.15 \%)$.

$>$ The highest production of buckwheat in the world of $93.67 \%$ was realized in Europe and Asian. The most significant buckwheat producers in the world are: China (34.25\%), Russia (32.43\%) and Ukraine (11.46 \%).

Average buckwheat yield produced in Bački Petrovac for tested varieties in 20102011 , amounted to average of 2,263 $\mathrm{kg} \mathrm{ha}^{-1}$. Genotype, year and their interaction in 2010-2011 showed statistical significance. More favourable year for buckwheat production was 2010. Statistically significantly higher yield was produced in 2010 in comparison to 2011.

Analysis of average buckwheat yield in the period 2010-2011 showed that Novosadska variety produced statistically significantly higher yield in relation to other tested varieties. 
Buckwheat can successfully be produced in Serbia because buckwheat yield was significantly higher than average world yield of $1,350 \mathrm{~kg} \mathrm{ha}^{-1}$.

\section{Literature}

1. Arsić, I., Dražić, S., Jevđović, R. (2008): Lekovita svojstva heljde, IX dani lekovitog bilja, 17-20 Septembar, Kosmaj, Zbornik apstrakata, pp. 108-109.

2. Berenji, J. (2011): Doprinos alternativnih biljnih vrsta agrobiodiverzitetu. Zbornik referata sa konferencije - Otvoreni dani biodiverziteta, Ured. Filipović, V., Ugrenović, V, Organska proizvodnja i biodiverzitet, 2012, Pančevo, pp. 48-55.

3. Đukić, M., Gadžo, D., Gavrić, T., Muminović, Š. (2007): Allelopathic potential of buckwheat, IV Symposium on Plant Protection in BiH, Teslic, Proceedings of Apstracts, pp. 28-29.

4. Glamočlija, Đ., Glamočlija, M., Cvijanović, G. (2011): Heljda, Monografija, Poljoprivredni fakultet, Beograd.

5. Ikanović, J., Rakić, S., Popović, V., Janković, S., Glamočlija, Đ., Kuzevski, J. (2013): Agro-ecological conditions and morpho-productive properties of buckwheat, Biotechnology in Animal Husbandry vol. 29(3), pp. 555562.

6. Kreft, I. (1995): Buckwheat, Ajda CZD Kmečki glas, Ljubljana, Slovenia.

7. Nikolić, Lj., Latković, D., Berenji, J., Sikora, V. (2010): Morphplogical characteristics of different cultivars of buckwheat (Fagopyrum esculentum Moench), Bilten za alternativne biljne vrste, Novi Sad, vol. 42(83), pp. 53-59.

8. Popović, V., Glamočlija, Đ., Malešević, M., Ikanović, J., Dražić, G., Spasić, M., Stanković, S. (2011): Genotype specificity in nitrogen nutrition of malting barley, Genetika, Belgrade, vol. 43(1), pp. 197-204, available at: www.dsggenetika.org.rs

9. Popović, V., Sarić, R., Jovanović, M. (2012): Sustainability of Agriculture in Danube basin area, Economics of Agriculture, vol. 59(1), IEP Belgrade, pp. 73-87.

10. Popović, V., Sikora, V., Berenji, J., Glamočlija, Đ., Marić, V. (2013a): Effect of agroecological factors on buckwheat yield in convential and organic cropping systems, Institute of PKB Agroeconomik, Belgrade, vol. 19(1-2), pp. 155-165.

11.Popović, V., Sikora, V., Ikanovic, J., Rajičič, V., Maksimović, L., Katanski, S. (2013b): Production, productivity and quality of buckwheat in organic growing systems in course environmental protection, XVII Eco-Conference, Novi Sad, 2528 Sept. pp. 395-404.

12.Popović, V., Sikora, V., Adamović, D., Glamočlija, Đ., Ikanović, J., Rajičić, V. (2013c): Effect foliar fertilization on yield and quality of buckwheat seed in organic growing systems, Bilten za alternativne biljne vrste, Novi Sad, vol. 45(86), pp. 55-59. 
13.Popović, V., Sikora, V., Glamočlija, Đ., Ikanović, J., Filipović, V., Tabakovic, M. Simić, D. (2013d): Influence of agro-ecological conditions and foliar fertilization on yield and yield components of buckwheat in conventional and organic cropping system, Biotechnology in Animal Husbandry, vol. 29(3), pp.537-546.

14. Sharma, T., Jana, S. (2002): Species relationships in Fagopyrum revealed by PCRbased DNA fingerprinting, Theoretical and Applied Genetics, vol. 105 (2-3), pp. 306-312.

15.http://faostat.fao.org/ 


\title{
ANALIZA PROIZVODNJE HELJDE U SVETU I U SRBIJI ${ }^{9}$

\author{
Vera Popovićc ${ }^{10}$, Vladimir Sikora ${ }^{11}$, Janoš Berenji ${ }^{12}$, Vladimir Filipovićc ${ }^{13}$, \\ Željko Dolijanovićc ${ }^{14}$, Jela Ikanović ${ }^{15}$, Dalibor Dončićc ${ }^{16}$
}

\begin{abstract}
Sažetak
U svetu je, u periodu 2010-2011., pod usevom heljde bilo zasejano godišnje u proseku oko 2,113 miliona ha. Prosečni prinosi heljde u posmatranom periodu iznosili su $913 \mathrm{~kg} \mathrm{ha}^{-1}$. Površine i prinosi beleže trend rasta po stopi od 22,46\% i 17,12\% godišnje. Najznačajni proizvođači heljde u svetu su: Kina, Rusija i Ukrajina. U Srbiji se heljda proizvodi na malim površinama.

U radu su prikazani i rezultati ispitivanja četiri sorte heljde, proizvedene na parcelama Instituta za ratarstvo i povrtarstvo: Novosadska, Godijevo, Bamby i Češka. Analiza prosečnih prinosa pokazala je da je sorta Novosadska ostvarila statistički značajno viši prinos (2626 kg ha-1) u odnosu na ostale ispitivane sorte $(p<0,05)$.

Iz prikazanih rezulata vidimo da su prinosi heljde u Srbiji značajno viši u odnosu na prosečne svetske prinose što nam govori da se ova gajena biljka može uspešno proizvoditi i u našim agroekološkim uslovima gajenja.
\end{abstract}

Ključne reči: heljda-Fagopyrum esculentum, površine, prinos, svet, Srbija.

9 Rad je deo istraživanja u okviru projekta TR 31022 koga finansira Ministarstvo za prosvetu, nauku i tehnološki razvoj Republike Srbije. Period trajanja projekta: 2011-2014.

10 Dr Vera Popović, Naučni saradnik, Institut za ratarstvo i povrtarstvo, Maksima Gorkog 30, 21000 Novi Sad, Srbija, Telefon: +381 6482057 33, E-mail: vera.popovic@nsseme.com

11 Dr Vladimir Sikora, Naučni saradnik, Institut za ratarstvo i povrtarstvo, Maksima Gorkog 30, 21000 Novi Sad, Srbija, E-mail: vladimir.sikora@nsseme.com

12 Dr Janoš Berenji, Naučni savetnik, Institut za ratarstvo i povrtarstvo, Maksima Gorkog 30, 21000 Novi Sad, Srbija, E-mail: janos.berenji@nsseme.com

13 Dr Vladimir Filipović, Naučni saradnik, Institut za proučavanje lekovitog bilja "Dr Josif Pančić", 11000 Beograd, Srbija, Telefon: +381 6486109 23, E-mail: vfilipovic@mocbilja.rs

14 Prof. dr Željko Dolijanović, Univerzitet u Beogradu, Poljoprivredni Fakultet, Nemanjina 6, 11080 Zemun, Srbija, Telefon: +381 6383063 68, E-mail: dolijan@agrif.bg.ac.rs

15 Dr Jela Ikanović, Naučni saradnik, Univerzitet u Beogradu, Poljoprivredni Fakultet, Nemanjina 6, 11080 Zemun, Srbija, E-mail: jela@agrif.bg.ac.rs

16 Dalibor Dončić, M.Sc., Syngenta, Meše Selimovića 12, Gradiška, Bosna i Hercegovina, Telefon: +387 65814 709, E-mail: dalibor.doncic@syngenta.com 